\title{
Peranan Tenaga Kerja dan Investasi Terhadap Produksi Industri Penyulingan Nilam di Kabupaten Aceh Jaya
}

\author{
Reza Septian Pradana ${ }^{1}$ \\ ${ }^{1}$ Fungsional Statistisi Ahli BPS Kabupaten Aceh Jaya \\ e-mail: reza.sp@bps.go.id \\ Diterima: November 2019, Disetujui: Desember 2019, Dipublish: April 2020
}

\begin{abstract}
Abstrak
Kabupaten Aceh Jaya menjadi daerah penghasil nilam terbaik di Aceh. Kadar patchouli oil yang dihasilkan di atas 30 persen menjadikan nilam yang dihasilkan di Aceh Jaya memiliki nilai ekonomis yang tinggi. Kondisi ini seharusnya dapat meningkatkan gairah industri penyulingan nilam di Kabupaten Aceh Jaya. Namun demikian, perkembangan industri penyulingan nilam juga tidak lepas dari peranan tenaga kerja dan investasi pada industri tersebut. Penelitian ini bertujuan untuk menganalisis peranan tenaga kerja dan investasi terhadap produksi industri penyulingan nilam di Kabupaten Aceh Jaya. Sampel dalam penelitian ini adalah 51 industri penyulingan nilam skala mikro dan kecil di Kabupaten Aceh Jaya. Penelitian ini menggunakan analisis regresi linier berganda. Hasil estimasi menunjukkan bahwa investasi secara signifikan berpengaruh positif terhadap produksi industri penyulingan nilam sedangkan tenaga kerja tidak secara signifikan berpengaruh terhadap produksi industri penyulingan nilam di Kabupaten Aceh Jaya. Dengan demikian, pemerintah daerah dan instansi terkait harus mampu menarik minat investor serta memberikan pelatihan baik manajerial maupun teknis untuk meningkatkan kualitas pekerja pada industri penyulingan nilam di Kabupaten Aceh Jaya.
\end{abstract}

Kata kunci: industri, investasi, penyulingan nilam, produksi, tenaga kerja

\begin{abstract}
Aceh Jaya regency becomes the best patchouli producing area in Aceh. Patchouli oil levels produced above 30 percent make patchouli produced in Aceh Jaya have high economic value. This condition should be able to increase the passion of patchouli distillation industry in Aceh Jaya Regency. However, the development of the patchouli distillation industry cannot be separated from the role of labor and investment in the industry. This study aims to analyze the role of labor and investment to production of patchouli distillation industry in Aceh Jaya Regency. The sample in this study was 51 micro and small scale patchouli distillation industries in Aceh Jaya Regency. This study uses multiple regression analysis. The result of estimation shows that investment significantly gives positive influence to production patchouli distillation in Aceh Jaya Regency while labor insignificantly influents to production of patchouli distillation industry in Aceh Jaya Regency. Thus, local government and relevant agencies have to be able to increase the interest of investor and gives training both managerial and technical to increase the workers' quality of patchouli distillation industry in Aceh Jaya Regency.
\end{abstract}

Keyword: industry, investment, labor, patchouli distillation, production 


\section{PENDAHULUAN}

Sejak dulu, Provinsi Aceh yang merupakan provinsi paling barat Indonesia sangat dikenal sebagai daerah dengan kekayaan alam yang melimpah. Selain dikenal dengan kopi nya yang khas, terdapat satu hasil perkebunan lainnya yang cukup menjadi perhatian berbagai pihak, yakni nilam yang merupakan bahan baku industri kosmetik, parfum dan farmasi. Hingga kini, nilam di Aceh menjadi jawara dengan kualitas mutu terbaik di dunia (Pikiran Merdeka, 5 Agustus 2012). Nilam Aceh pernah mengalami masa kejayaan di tahun 20-an (Nad.litbang.pertanian.go.id, 2017). Pada masa itu, Belanda mulai membangun unit-unit usaha untuk melakukan penyulingan tanaman nilam untuk diambil minyaknya. Minyaknya sangat laku dan bernilai ekonomi tinggi di pasaran dunia.

Kualitas minyak nilam Aceh tidak terlepas dari tanahnya yang subur dan berada di jalur khatulistiwa. Tanaman ini terkena pancaran sinar matahari yang cukup. Luas lahan di Provinsi Aceh yang dipergunakan untuk perkebunan nilam hanya sekitar 2.010 hektar dengan jumlah petani di kisaran 6.248 KK dan poduktivitas mencapai $321 \mathrm{~kg}$ per hektare (Ditjenbun.pertanian.go.id 2015-2017).

Kabupaten Aceh Jaya menjadi daerah penghasil nilam terbaik di Aceh. Adapun luas tanaman nilam di Aceh Jaya sejak tahun 2013 - 2018 telah mencapai 238,5 hektar dengan jumlah produksi sebanyak 37,8 ton minyak nilam per tahun, dengan tingkat produktivitas 166 Kg per hektar.
Wakil Rektor I Unsyiah Prof Marwan dalam aceh.antaranews.com edisi 26 Juni 2019 mengatakan bahwa Nilam Aceh khususnya yang ditanam di Aceh Jaya telah menjadi perbincangan nasional baik di Kemenristekdikti ataupun Bappenas karena nilam Aceh memiliki beberapa keunikan. Beberapa keunikan nilam Aceh diantaranya kadar patchouli oil yang bisa di atas 30 persen, jumlah minyak yang dihasilkan dalam sekali penyulingan atau rendemen pada nilam Aceh bisa mencapai tiga persen. Berdasarkan informasi dari Pikiran Merdeka edisi 5 Agustus 2012, minyak nilam Aceh Jaya di pasarkan hingga ke luar negeri, yakni seperti negara Amerika dan Perancis dengan harga jualnya yang tinggi dan mencapai satu juta rupiah perkilo gramnya.

Karena secara ekonomis mempunyai nilai tambah lebih tinggi, diharapkan gairah industri minyak nilam di Kabupaten Aceh Jaya semakin meningkat. Potensi tersebut perlu dilakukan pengolahan lebih lanjut sehingga memberikan nilai tambah yang lebih besar. Pada akhirnya, kesejahteraan petani nilam Aceh Jaya meningkat. Dengan demikian, perlu dilakukan upaya peningkatan sektor industri, khususnya industri penyulingan nilam di Kabupaten Aceh Jaya.

Salah satu indikator untuk melihat perkembangan sektor industri adalah dengan mengukur nilai produksi dari masing-masing kelompok industri. Untuk menghasilkan hasil produksi dengan baik, maka diperlukan rangkaian 
kegiatan yang membentuk suatu sistem produksi (Islamy, 2014).

Proses produksi baru bisa berjalan bila persyaratan yang dibutuhkan dapat dipenuhi dan persyaratan ini lebih dikenal dengan nama faktor produksi (Daniel, 2002). Suhartati dan Fathorozi (2003) mengatakan bahwa produksi merupakan hasil akhir dari proses aktivitas ekonomi dengan memanfaatkan beberapa masukan atau input. Input produksi ini dapat berupa bahan baku, mesin, tenaga kerja, modal, dan informasi. Dengan demikian, kegiatan produksi mengkombinasikan berbagai input atau masukan untuk menghasilkan output (Amalia, 2014). Analisis pengaruh input terhadap output dijelaskan dalam suatu fungsi produksi.

Fungsi produksi yang umumnya digunakan adalah fungsi produksi dari Cobb Douglas. Fungsi Cobb-Douglas adalah suatu fungsi atau persamaan yang menunjukkan pengaruh input yang digunakan dengan output yang diinginkan. Fungsi produksi CobbDouglas ini melihat bagaimana pengaruh stok kapital (investasi) dan tenaga kerja yang digunakan dengan menganggap teknologi yang digunakan konstan.

Untuk mendapatkan produksi maksimum, diperlukan adanya peningkatan investasi. Menurut Amelia (2017), investasi adalah salah satu penentu pertumbuhan ekonomi karena dengan adanya investasi dapat menaikkan output secara signifikan. Istilah investasi dapat diartikan sebagai pengeluaran yang dilakukan investor atau perusahaan untuk membeli barang modal dan perlengkapan produksi demi menambah kemampuan memproduksi barang serta jasa yang tersedia dalam perekonomian (Sukirno, 2009). Keynes menyebutkan investasi dapat meningkatkan permintaan agregat. Selain itu, investasi memengaruhi penawaran agregat melalui pengaruhnya terhadap kapasitas produksi. Kapasitas produksi ini akan berpengaruh terhadap produksi. Berdasarkan data Disperindagkop Kabupaten Aceh Jaya, investasi pada industri penyulingan nilam di Kabupaten Aceh Jaya pada tahun 2018 berkisar antara 10 juta hingga 450 juta rupiah.

Kualitas dan kuantitas produksi sangat ditentukan oleh tenaga kerja meskipun peran dan fungsi dari tenaga kerja telah banyak digantikan dengan mesin-mesin industri. Setiap industri menghendaki agar setiap tenaga kerja dapat bekerja secara efektif dan efisien sehingga menjadi tenaga kerja yang profesional, tenaga kerja yang memiliki keterampilan dan kemampuan sehingga mampu bekerja lebih produktif sehingga mampu memenuhi target produksi (Novitri, 2015). Industri penyulingan nilam di Kabupaten Aceh Jaya sebagian besar masih berskala mikro dan kecil dimana rata-rata jumlah tenaga kerja sekitar 2 hingga 3 orang. Dengan penambahan jumlah tenaga kerja yang memiliki keahlian baik dari sisi manajerial maupun teknis diharapkan dapat meningkatkan produksi minyak nilam di Kabupaten Aceh Jaya.

Penelitian terkait pengaruh tenaga kerja dan investasi terhadap 
produksi suatu industri sudah banyak dilakukan. Hasil penelitian yang dilakukan oleh Jamli (2012), Fachrizal (2016), Anwar dan Saputra (2018), dan Deviyanova (2018) menunjukkan bahwa tenaga kerja dan imvestasi secara signifikan berpengaruh positif terhadap produksi suatu industri. Hal ini berarti setiap kenaikan jumlah tenaga kerja dan nilai investasi akan meningkatkan nilai produksi suatu industri.

Berdasarkan pemikiran diatas, diperlukan suatu analisis untuk mengetahui pengaruh tenaga kerja dan investasi terhadap produksi industri penyulingan nilam di Kabupaten Aceh Jaya. Dengan demikian, diperoleh informasi terkait upaya yang dapat dilakukan untuk meningkatkan produksi industri penyulingan nilam di Kabupaten Aceh Jaya.

Hipotesis yang digunakan dalam penelitian ini adalah tenaga kerja dan investasi berpengaruh positif terhadap produksi industri penyulingan nilam di Kabupaten Aceh Jaya.

\section{METODE PENELITIAN}

Penelitian dilakukan pada lima puluh satu industri penyulingan nilam skala mikro dan kecil di Kabupaten Aceh Jaya. Pemilihan sampel dilakukan secara purposive sampling yakni seluruh industri penyulingan nilam skala mikro dan kecil yang secara rutin memberikan laporan keuangannya kepada Dinas Perindustrian, Perdagangan, Koperasi, dan UKM (Disperindagkop) Kabupaten Aceh Jaya.

Data yang digunakan dalam penelitian ini adalah data sekunder berupa data cross section tenaga kerja, investasi, dan produksi lima puluh satu industri penyulingan nilam di Kabupaten Aceh Jaya tahun 2018. Data bersumber dari database Disperindagkop Kabupaten Aceh Jaya. Variabel dependen dalam penelitian ini yaitu tenaga kerja dan investasi industri penyulingan nilam di Kabupaten Aceh Jaya. Kemudian, variabel bebas dalam penelitian ini yaitu produksi industri penyulingan nilam di Kabupaten Aceh Jaya.

Metode analisis yang digunakan dalam penelitian ini adalah analisis regresi linier berganda. Model yang akan digunakan dalam penelitian ini adalah sebagai berikut:

$\ln P_{i}=\beta_{0}+\beta_{1} \ln T K_{i}+\beta_{2} \ln I N V_{i}+e_{i}$ dimana:

$P_{i} \quad=$ Nilai Produksi industri penyulingan nilam $i$ (milyar rupiah)

$\beta_{0} \quad=$ Intersep

$\beta_{1}, \beta_{2}=$ Koefisien Regresi Variabel Independen

$T K_{i} \quad=$ Jumlah Tenaga Kerja industri penyulingan nilam $i$ (orang)

$I N V_{i}=$ Investasi industri penyulingan nilam $i$ (juta rupiah)

$e_{i} \quad=$ error term industri penyulingan nilam $i$

$i \quad=$ industri penyulingan nilam $(1,2, \ldots, 51)$

Agar memperoleh penduga yang bersifat BLUE (Best Linier Unbiased Estimator), pada penelitian ini dilakukan berbagai pengujian terhadap data dan model yang terbentuk, seperti uji asumsi dasar (uji Normalitas dan Non Multikolinearitas) 
serta Uji Keberartian Model (Uji F dan Uji t).

Gujarati (2004) mengatakan bahwa semua statistik parametrik termasuk regresi linier berganda mensyaratkan asumsi-asumsi yang harus dipenuhi sebelum estimasi model dilakukan. Pelanggaran terhadap satu atau beberapa asumsi saja mungkin akan menyebabkan masalah yang serius seperti koefisien regresi menjadi bias, standar error menjadi bias dan nilai $R^{2}$ serta pengujian signifikansi menjadi tidak tepat/ misleading. Dengan demikian, perlu dilakukan pengujian terhadap asumsi-asumsi tersebut.

\section{HASIL DAN PEMBAHASAN}

Kondisi Tenaga Kerja, Investasi, dan Produksi Industri Penyulingan Nilam di Kabupaten Aceh Jaya

Tabel 1. Statistik Deskriptif Tenaga Kerja, Investasi, dan Produksi Industri Penyulingan Nilam di Kabupaten Aceh Jaya Tahun 2018

\begin{tabular}{cccc}
\hline & TK & INV & P \\
\hline Mean & 2,4902 & 73,1176 & 2,6760 \\
Maximum & 1,00 & 10,00 & 0,72 \\
Minimum & 6,00 & 450,00 & 7,13 \\
$C V$ & $51,03 \%$ & $100,04 \%$ & $38,93 \%$ \\
\hline
\end{tabular}

Jumlah tenaga kerja industri penyulingan nilam di Kabupaten Aceh Jaya pada tahun 2018 berada pada kisaran 1 orang hingga 6 orang atau secara rata-rata tidak jauh dari 2 orang. Hal ini menunjukkan bahwa sebagian besar industri penyulingan nilam di Kabupaten Aceh Jaya pada tahun 2018 berskala mikro.

Nilai investasi industri penyulingan nilam di Kabupaten Aceh Jaya pada tahun 2018 berada pada kisaran 10 juta hingga 450 juta. Secara rata-rata, total investasi yang tersalurkan pada industri penyulingan nilam di Kabupaten Aceh Jaya pada tahun 2018 tidak jauh dari 73,12 juta.
Nilai produksi industri penyulingan nilam di Kabupaten Jaya berada pada kisaran 0,72 milyar hingga 7,13 milyar.

Secara rata-rata, nilai produksi pada industri penyulingan nilam di Kabupaten Aceh Jaya pada tahun 2018 tidak jauh dari 2,68 milyar.

Variabel investasi memiliki tingkat keragaman data tertinggi. Hal ini ditunjukkan dengan nilai Coefficient of Variation (CV) sebesar 100,04 persen. Ini berarti data investasi industri penyulingan nilam di Kabupaten Aceh Jaya sangat beragam apabila dibandingkan variabel tenaga kerja dan produksi. Sebaliknya, nilai produksi industri penyulingan nilam di Kabupaten Aceh Jaya memiliki tingkat keragaman data terendah dengan nilai CV sebesar 38,93 persen. Ini berarti data nilai produksi industri 
penyulingan nilam di Kabupaten Aceh Jaya kurang begitu beragam.

\section{Pembentukkan Model Terbaik dan} Pengujian Asumsi Dasar

Tabel 2. Model Persamaan Pertumbuhan Produksi Industri Penyulingan Nilam di Kabupaten Aceh Jaya Tahun 2018

\begin{tabular}{ccccccc}
\hline $\begin{array}{c}\text { Variabel } \\
\text { Dependen }\end{array}$ & $\begin{array}{c}\text { Variabel } \\
\text { Independen }\end{array}$ & Koefisien & t-statistic & P-value & \multicolumn{2}{c}{ Ringkasan Statistik } \\
\hline \multirow{2}{*}{$P_{i}$} & Konstanta & 11,67 & 19,630 & 0,000 & Adjusted & \multirow{2}{*}{0,858} \\
& $\ln T K_{i}$ & $-0,79$ & $-1,544$ & 0,129 & Prob & \multirow{2}{*}{0,000} \\
& $\ln I N V_{i}$ & 0,57 & 16,436 & 0,000 & $($ F-stat $)$ & \\
\hline
\end{tabular}

Keterangan:

* Signifikan pada taraf nyata/ alpha 5 persen

Dalam penelitian ini, salah satu pengujian asumsi dasar yang dilakukan adalah pengujian normalitas. Pengujian normalitas pada model pertumbuhan produksi industri penyulingan nilam di Kabupaten Aceh Jaya menggunakan Normal P-P Plot. Dengan menggunakan bantuan software SPSS 22, diperoleh hasil sebagai berikut:

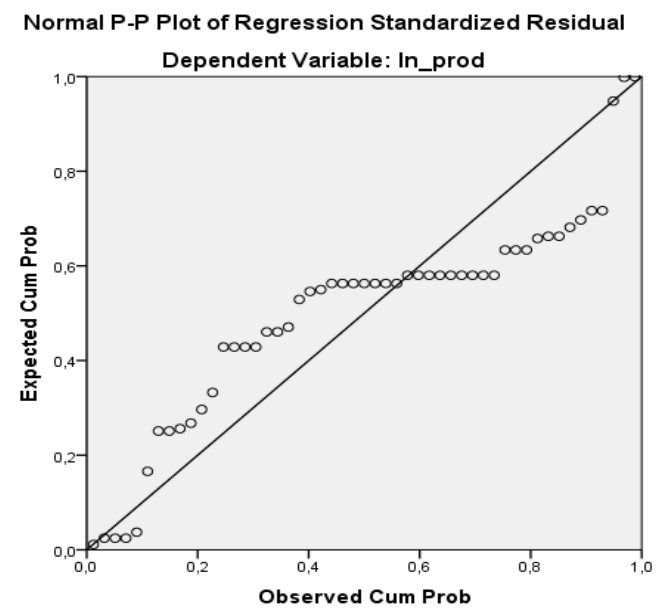

Gambar 1. Normal P-P Plot of Regression Standardized Residual
Dengan menggunakan software SPSS 22, model terbaik yang terbentuk dalam penelitian ini adalah sebagai berikut:
Berdasarkan gambar diatas, terlihat bahwa data menyebar disekitar garis diagonal dan mengikuti arah garis diagonal. Dengan demikian, dapat disimpulkan bahwa data yang digunakan dalam pembentukkan model pertumbuhan produksi indutri penyulingan nilam di Kabupaten Aceh Jaya berdistribusi normal.

Pengujian asumsi nonmultikolinieritas pada penelitian ini menggunakan uji formal yakni berdasarkan nilai Variance Inflation Factor (VIF). Dengan menggunakan software SPSS 22, diperoleh hasil pengujian non-multikolinearitas sebagai berikut:

Tabel 3. Hasil Pengujian NonMultikolinearitas pada Variabel Bebas Model Terbaik

\begin{tabular}{cc}
\hline Variabel & $V I F$ \\
\hline $\ln T K_{i}$ & 1,213 \\
$\ln I N V_{i}$ & 1,213 \\
\hline
\end{tabular}

Asumsi Non-Multikolinearitas atas seluruh variabel bebas yang digunakan dalam model sudah 
terpenuhi. Hal ini dibuktikan dengan nilai Variance Inflation Factor (VIF) untuk seluruh variabel jauh lebih kecil dari 10 sehingga dapat disimpulkan tidak terjadi hubungan antara variabel bebas yang masuk ke dalam model.

Berdasarkan uji asumsi dasar di atas, dapat disimpulkan bahwa model yang terbentuk merupakan model terbaik. Model ini dapat digunakan untuk menganalisis pengaruh tenaga kerja dan investasi terhadap produksi industri penyulingan nilam di Kabupaten Aceh Jaya.

\section{Pengaruh Tenaga Kerja dan Investasi Terhadap Produksi Industri Penyulingan Nilam di Kabupaten Aceh Jaya}

Nilai Adjusted R-Square yang diperoleh sebesar 0,858 yang berarti bahwa variasi yang terjadi pada pertumbuhan produksi industri penyulingan nilam di Kabupaten Aceh Jaya dapat dijelaskan oleh tenaga kerja dan investasi sebesar 85,80 persen sedangkan sisanya sebesar 14,20 persen dijelaskan oleh variabel lain yang tidak masuk di dalam model, seperti bahan baku yang digunakan, kapasitas produksi, jumlah alat/mesin penyulingan nilam, dan sebagainya.

Secara overall, pertumbuhan tenaga kerja dan pertumbuhan investasi secara signifikan berpengaruh terhadap pertumbuhan produksi industri penyulingan nilam di Kabupaten Aceh Jaya. Hal ini ditunjukkan dengan nilai probabilitas uji F-statistic sebesar 0,0000 yang lebih kecil dari alpha 0,05.

Secara parsial, hanya variabel pertumbuhan investasi signifikan di dalam model. Hal ini ditunjukkan dengan nilai $p$-value uji $t$-statistic untuk semua variabel bebas tersebut lebih kecil dari alpha 0,05. Dengan demikian, dapat disimpulkan bahwa pertumbuhan investasi secara signifikan berpengaruh terhadap pertumbuhan produksi industri penyulingan nilam di Kabupaten Aceh Jaya.

Nilai koefisien pertumbuhan investasi sebesar 0,57 memiliki arti bahwa dengan tingkat kepercayaan 95 persen, peningkatan jumlah tenaga kerja sebesar 1 persen dapat meningkatkan produksi industri penyulingan nilam di Kabupaten Aceh Jaya sebesar 0,57 persen dengan asumsi variabel bebas lainnya tetap. Pengaruh positif investasi terhadap produksi sesuai dengan teori yang dihipotesiskan. Pengeluaran yang dilakukan investor atau perusahaan untuk membeli barang modal dan perlengkapan produksi industri penyulingan nilam dapat menambah kemampuan memproduksi minyak nilam sehingga dapat meningkatkan produksi industri penyulingan nilam di Kabupaten Aceh Jaya. Hal ini juga serupa dengan hasil penelitian yang dilakukan oleh Islamy (2014), Jamli (2012), Fachrizal (2016), Amelia (2017), Anwar dan Saputra (2018), Deviyanova (2018), serta Abidin dan Wiwoho (2019).

Pertumbuhan tenaga kerja tidak secara signifikan berpengaruh terhadap pertumbuhan produksi industri penyulingan nilam di Kabupaten Aceh Jaya. Tanda negatif pada koefisien pertumbuhan tenaga 
kerja menunjukkan bahwa kenaikan persentase jumlah tenaga kerja justru berpengaruh terhadap penurunan persentase produksi industri penyulingan nilam di Kabupaten Aceh Jaya. Pengaruh negatif dan tidak signifikannya variabel tenaga kerja terhadap produksi tidak sesuai dengan teori yang dihipotesiskan. Namun, pengaruh negatif tenaga kerja terhadap produksi serupa dengan hasil penelitian Amelia (2017) dan tidak signifikannya pengaruh tenaga kerja terhadap produksi serupa dengan hasil penelitian Islamy (2014) serta serta Abidin dan Wiwoho (2019). Hal ini menjadi indikasi bahwa produktivitas tenaga kerja pada industri penyulingan nilam di Kabupaten Aceh Jaya cenderung rendah sehingga penambahan jumlah tenaga kerja tidak berdampak pada peningkatan produksi. Sesuai dengan teori pertambahan hasil yang semakin menurun (The Law of Diminishing Return), pada awalnya penambahan jumlah tenaga kerja akan meningkatkan produksi kemudian tambahan produksi yang diciptakan oleh tambahan tenaga kerja semakin lama menjadi semakin berkurang.

\section{SIMPULAN}

Investasi secara signifikan berpengaruh positif terhadap produksi industri penyulingan nilam di Kabupaten Aceh Jaya. Dengan demikian, diperlukan upaya dari Pemerintah Daerah Kabupaten Aceh Jaya dan instansi terkait untuk menarik minat investor terutama investor dalam negeri dalam merealisasikan investasinya. Upaya yang dapat dilakukan pemda diantaranya meningkatkan keamanan, memberikan jaminan kepastian hukum, menjaga stabilitas ekonomi, menyediakan infrastruktur yang baik, membuat peraturan yang tidak menyulitkan investor, serta mempermudah prosedur dan izin usaha.

Sebaliknya, tenaga kerja tidak secara signifikan berpengaruh terhadap produksi industri penyulingan nilam di Kabupaten Aceh Jaya. Pemerintah daerah dan instansi terkait diharapkan dapat meningkatkan kualitas Sumber Daya Manusia (SDM) sehingga seluruh pekerja pada industri penyulingan nilam di Kabupaten Aceh Jaya memiliki kemampuan yang baik terutama dalam upaya peningkatan produksi industri nilam. Hal ini bisa dilakukan dengan pemberian pelatihan baik dari sisi manajerial maupun teknis kepada seluruh pekerja.

\section{DAFTAR PUSTAKA}

Abidin, Mohammad Zainal \& Wiwoho, Bambang. (2019). Analisis Tenaga Kerja dan Investasi Terhadap Nilai Produksi Industri Alas Kaki di Kabupaten Mojokerto. Jurnal Ekonomi \& Bisnis , 4 (1), 811-818.

Amalia, Fitri. (2018). Analisis Fungsi Produksi Cobb-Douglas pada Kegiatan Sektor Usaha Mikro di Lingkungan UIN Syarif Hidayatullah Jakarta. Signifikan, 3 (1), 45-62.

Amelia, Deni. (2017). Pengaruh Investasi dan Tenaga Kerja Terhadap Produksi Subsektor Perkebunan di Sumatera Barat. Majalah Ilmiah, 24 (1), 121-128.

Anwar, Khairil \& Saputra, Muhammad Yani. (2018). Pengaruh Investasi dan 
Tenaga Kerja Terhadap Produksi pada Industri Kecil di Kabupaten Aceh Utara. Jurnal Ekonomi Regional Unimal, 1 (2), 28-33.

Daniel M. (2002). Pengantar Ekonomi Pertanian. Jakarta: Bumi Aksara.

Deviyanova, Hana. (2018). Analisis Pengaruh Jumlah Tenaga Kerja, Nilai Investasi, Bahan Baku, dan Teknologi Terhadap Nilai Produksi Pada Sektor Industri Kecil Pembuatan Genteng di Kebakkramat Karanganyar Tahun 2017. Surakarta: Universitas Muhammadiyah Surakarta.

Fachrizal. (2016). Pengaruh Modal dan Tenaga Kerja Terhadap Produksi Industri Kerajinan Kulit di Kabupaten Merauke. Jurnal Ilmiah Agribisnis dan Perikanan (agrikan UMMU-Ternate), 9 (2), 66-75.

Gujarati, Damodar N. (2004). Basic Econometrics: Forth Edition. Mc. Graw Hill Companies.

Islamy, Talitha. (2014). Pengaruh Investasi dan Tenaga Kerja terhadap
Produksi Industri Kecil di Surabaya. Surabaya: Unesa

Jamli. (2012). Pengaruh Investasi dan Tenaga Kerja Terhadap Produksi Batubara dan Pertumbuhan Ekonomi di Kutai Kartanegara. Jurnal Eksis, 8 (2), 2168-2375.

Novitri, Irma Amalia. (2015). Pengaruh Tenaga Kerja dan Bahan Baku Terhadap Peningkatan Hasil Produksi Pada Industri Tempe (Studi Kasus di Desa Bojongsari Kabupaten Indramayu [Skripsi]. Cirebon: Institut Agama Islam Negeri Syekh Nurjati Cirebon.

Suhartati, Tati \& Fathorozi. (2003). Teori Ekonomi Mikro Edisi I. Salemba Empat: Jakarta.

Sukirno, S. (2009). Teori Pengantar Ekonomi mikro. Jakarta: Raja Grafindo Persada. 